\title{
Polski rynek finansowy po wejściu Polski do strefy euro
}

\begin{abstract}
Polish financial market after the possible joining the eurozone: The aim of the article is to assess the possible effects of joining the eurozone by Poland for its financial market. Special attention is paid to banking and capital markets. The author emphasises the necessity of incurring additional fees by banks, loss of some income (directly related to currency exchange) and opportunity to obtain additional income (resulting from higher loan margins). Next, the author discusses opportunities and challenges related to capital market development, including the risk of reducing turnover in certain segments (for example: derivatives market).
\end{abstract}

Słowa kluczowe: rynek finansowy, rynek bankowy, rynek kapitałowy, strefa euro, Unia Europejska, unia bankowa, unia kapitałowa

Keywords: financial market, banking market, capital market, eurozone, European Union, banking union, capital union

* Doktor nauk ekonomicznych, Szkoła Główna Handlowa w Warszawie, Kolegium Gospodarki Światowej, Katedra Rynków Kapitałowych • e-mail: malgorzata.mikita@sgh.waw.pl • https://orcid.org/oooo-0002-3831-6698

\section{Wstęp}

Wejście Polski do strefy euro pozostaje kwestią otwartą od roku 2004, kiedy to Polska weszła do Unii Europejskiej (UE). Podpisanie przez Polskę traktatu stowarzyszeniowego było jednocześnie deklaracją wejścia do Unii Gospodarczej i Walutowej (UGW) po spełnieniu kryteriów konwergencji (tj. kryteriów dotyczących: stabilności cen, kursu walutowego i stóp procentowych oraz długotrwałej równowagi finansów publicznych ${ }^{1}$ ).

W 2004 r. Polska nie spełniała tych kryteriów, dlatego też nasze członkostwo zostało odłożone w czasie (tzw. członkostwo z derogacją, art. 140 TFUE). Nie

1 Traktat o funkcjonowaniu Unii Europejskiej, Dz.Urz. UE C 326/47 z 26 października 2012 r.; TFUE. 
określono żadnych ram czasowych kończących ten proces, bazując na przekonaniu, że oczywiste jest, że każdy kraj członkowski będzie chciał jak najszybciej wejść do strefy euro z uwagi na liczne korzyści z tego wynikające. Przekonanie to, podobnie jak przewidywane korzyści z członkostwa, okazało się mylne. Kryzys strefy euro (po roku 2007) zniechęcił Polskę (podobnie jak inne kraje unijne pozostające poza strefą euro) do wejścia w jej struktury. UGW znalazła się w okresie recesji (podczas kryzysu $2008 \mathrm{r}$. wzrost gospodarczy w strefie euro wyniósł zaledwie 0,4\%). Wiele krajów (szczególnie Grecja, Irlandia, Hiszpania i Portugalia) odnotowało wyraźne kłopoty finansowe. W obliczu niepewności co do przyszłości strefy euro, dodatkowo zwiększonej brexitem (wyjściem Wielkiej Brytanii z UE) i skutkami tego procesu dla funkcjonowania UE, w tym także strefy euro, członkostwo Polski w strefie euro wydaje się pozostawać w najbliższych latach kwestią otwartą.

Szybka akcesja do strefy euro nie jest pożądana $\mathrm{z}$ uwagi na brak stabilności Eurolandu. Nie jest ona też możliwa. Jak wynika z ostatniego raportu ${ }^{2}$ Komisji Europejskiej ${ }^{3}$ dotyczącego stopnia realizacji kryteriów z Maastricht przez kraje będące członkami UE, ale nie będące członkami UGW (tj. Polskę, Bułgarię, Chorwację, Czechy, Danię, Rumunię, Szwecję i Węgry ${ }^{4}$ ) z czerwca 2018 r., Polska nie spełnia kryteriów przyjęcia euro (analizowano sytuację w Polsce, bazując na danych z marca 2018 r. $)^{5}$. Podkreślono, że Polska nie spełnia warunku w zakresie stabilności kursu walutowego (polski złoty nie został wprowadzony do mechanizmu ERM II ${ }^{6}$ ) oraz stabilności długoterminowych stóp procentowych ${ }^{7}$.

2 Komisja Europejska, Convergence Report, May 2018, https://ec.europa.eu/info/sites/ info/files/economy-finance/ip078_en.pdf [dostęp: 20 maja 2019 r.].

3 Komisja Europejska odpowiedzialna jest za monitorowanie konwergencji Polski i pozostałych krajów pozostających poza strefą euro. Jeśli Polska spełniałaby wszystkie kryteria konwergencji, Komisja wnioskowałaby o zniesienie derogacji. Ostateczną decyzję o przyjęciu Polski do UGW podjęliby ministrowie finansów strefy euro większością kwalifikowaną, po konsultacji z Parlamentem Europejskim oraz Radą Europejską. Kurs wymiany złotego na euro zostałby określony jednomyślną decyzją państw strefy euro i Polski, po konsultacji z Europejskim Bankiem Centralnym.

${ }^{4} \mathrm{~W}$ raporcie nie ujęto Danii, z uwagi na wprowadzenie duńskiej korony w roku 2015 do ERM II (Exchange Rate Mechanism), oraz Wielkiej Brytanii z uwagi na brexit.

${ }^{5}$ Kolejny raport Komisji Europejskiej nt. konwergencji ukaże się w 2020 r.

${ }^{6}$ Należy podkreślić, że stabilność kursu walutowego złotego do euro jest bardzo wysoka, co oznacza, że Polska byłaby w stanie spełnić to kryterium konwergencji (gdyby przyłączyła się do ERM II).

7 Komisja Europejska bierze pod uwagę stopy procentowe NBP ustalane przez Radę Polityki Pieniężnej na podstawie rentowności długoterminowych obligacji skarbowych lub porównywalnych papierów wartościowych. Długoterminowe stopy procentowe mogą najwyżej o 2 punkty procentowe przekraczać stopy trzech najstabilniejszych pod tym względem państw członkowskich. W Polsce stopy procentowe NBP w kwietniu 2018 r. kształtowały się na poziomie 3,3\%, natomiast tzw. wartość referencyjna wynosiła $2,7 \%$. 
Ponadto wskazano na brak zgodności polskich przepisów z przepisami strefy euro ${ }^{8}$, akcentując, że polskie prawo nie zapewnia w wystarczający sposób niezależności Narodowego Banku Polskiego jako banku centralnego?.

Należy zauważyć, że obok kryteriów z Maastricht, jakie musi spełnić kraj dążący do członkostwa w strefie euro, tzw. kryteriów twardych, kandydaci do UGW muszą spełniać też dodatkowe wymagania, określane jako kryteria miękkie. Wymagania te zostały wprowadzone po roku 2008, kiedy rozpoczęto intensywny proces reformowania UE. Kryteria miękkie są brane pod uwagę przy ocenie konwergencji, chociaż nie zamykają drogi do wejścia danego kraju w struktury strefy euro. Do grupy kryteriów miękkich należą niewątpliwie wymagania wynikające z nowego Paktu stabilności i wzrostu ${ }^{10}$, paktu fiskalnego ${ }^{11}$ czy utworzenia Europejskiego Mechanizmu Stabilności (EMS) ${ }^{12}$. W Pakcie stabilności i wzrostu przedstawiono nowe wskaźniki konwergencji w ramach tak zwanej procedury nierównowag makroekonomicznych (dotyczą one: bilansów handlowych państw, stopnia zadłużenia sektora finansowego, dynamiki cen nieruchomości $)^{13}$. W pakcie fiskalnym zobowiązano kraje członkowskie strefy euro do wprowadzenia zapisów konstytucyjnych, które dotyczą maksymalnego długu publicznego (jego poziom nie może przekraczać 60\% PKB). Z faktu utworzenia w 2013 r. Europejskiego Mechanizmu Stabilności (którego zadaniem jest zapewnianie państwom członkowskim strefy euro, które borykają się z problemami budżetowymi, pomocy) wynika konieczność ponoszenia dodatkowych wpłat (ich wysokość zależy od poziomu PKB kraju) ${ }^{14}$.

${ }^{8}$ Komisja Europejska, Convergence Report, op. cit.

9 W raporcie o konwergencji z maja 2018 r. przedstawionym przez Komisję Europejską (Convergence Report, op. cit.) uznano za niezgodne z prawem unijnym trzy kwestie. Po pierwsze, konieczność przedstawiania przez Prezesa NBP ram polityki pieniężnej Radzie Ministrów i Ministrowi Finansów (uznano to za przejaw łamania zasady niezależności NBP). Po drugie, możliwość odwołania Prezesa NBP przez Trybunał Stanu. Po trzecie, zapis w Konstytucji RP (art. 227) mówiący o tym, że wyłączne prawo do emisji pieniądza i ustalania polityki pieniężnej w Polsce ma NBP.

10 European Commission Vade Mecum on the Stability \& Growth Pact, 2019, https:// ec.europa.eu/info/sites/info/files/economy-finance/ip101_en.pdf [dostęp: 19 czerwca 2019 r.].

11 ECB, A Fiscal Compact for a Stronger economic and Monetary Union, Monthly Bulletin, May 2012, https://www.ecb.europa.eu/pub/pdf/other/art1_mb201205en_pp79-94en.pdf?ea 087c02b73d02418533c67ea0d36c1c [dostęp: 17 maja 2019 r.].

12 European Parliament, The European Stability Mechanism: Main Features, Instruments and Accountability, 2019, http://www.europarl.europa.eu/RegData/etudes/ BRIE/2014/497755/IPOL-ECON_NT(2014)497755_EN.pdf [dostęp: 21 czerwca 2019 r.].

${ }_{13}$ Polska jest sygnatariuszem Paktu stabilności, niemniej nie obejmują jej wszystkie zapisy tego dokumentu (m.in. zapisy, które dotyczą automatycznej procedury ograniczania długu publicznego).

14 A. Czerniak, A. Smoleńska, Polska bez euro. Bilans kosztów i korzyści, Polityka Insight, 2019, s. 10-11, https://www.politykainsight.pl/en/_resource/multimedium/20164985 [dostęp: 22 maja 2019 r.]. 
Wydaje się, że z punktu widzenia Polski najlepszym rozwiązaniem jest dążenie do członkostwa w UGW, odsuwając jednak ten proces w czasie (do chwili stabilizacji sytuacji gospodarczej w Eurolandzie). Definitywna rezygnacja z członkostwa Polski w UGW nie jest dobrym rozwiązaniem. Rodzi bowiem ryzyko marginalizacji politycznej i gospodarczej naszego kraju.

Wejście Polski do strefy euro niewątpliwie wywrze istotny wpływ na naszą gospodarkę, zarówno na sferę realną, jak też sferę regulacyjną. Skutki tego procesu będą widoczne zarówno na rynku dóbr, usług i rynku pracy, jak też na rynku finansowym.

Niniejszy artykuł skupia się na rynku finansowym. Jego celem jest analiza skutków wejścia Polski do strefy euro dla polskiego rynku finansowego. Wśród analizowanych sektorów rynku finansowego znalazły się: rynek bankowy oraz rynek kapitałowy. Hipoteza badawcza brzmi: wejście Polski do strefy euro wywrze istotny wpływ na rynek finansowy w Polsce.

Należy podkreślić, że przedstawiona w artykule analiza skutków wejścia Polski do strefy euro na polski rynek finansowy opiera się na wiedzy (dotyczącej różnych rozwiązań prawnych, propozycji i planach rozwoju strefy euro) aktualnej na koniec maja 2019 r. Wobec pewnej dynamiki projektów w zakresie przyszłego kształtu UE ${ }^{15}$ warto mieć na względzie, iż przeprowadzona analiza powinna być aktualizowana, tak aby uwzględnić jak największą liczbę nowych rozwiązań i regulacji wprowadzanych w przyszłości (bądź też likwidację już wprowadzonych). Można założyć, że UGW w przyszłości będzie miała inny wymiar niż UGW obecnie. Przewiduje się następujące zmiany. Po pierwsze, wzmocnienie kontroli nad wielkością deficytów i długów publicznych (poczynione kroki w tym kierunku to: pakt fiskalny ${ }^{16}$, sześciopak ${ }^{17}$ czy dwupak $^{18}$; ponadto trwają dyskusje na temat osobnego budżetu strefy euro czy też powołania ministra finansów strefy euro). Po drugie, zwiększenie integracji finansowej

15 Komisja Europejska, Biała Księga w sprawie przyszłości Europy. Refleksje i scenariusze dotyczące przyszłości UE-27 do 2025 r., Bruksela 2017, https:/ec.europa.eu/commission/sites/ beta-political/files/biala_ksiega_w_sprawie_przyszlosci_europy_pl.pdf [dostęp: 22 kwietnia 2019 r.].

${ }_{16}$ ECB, A Fiscal Compact, op. cit.

17 Nazwą „sześciopak” określa się pakiet sześciu aktów legislacyjnych (pięciu rozporządzeń i jednej dyrektywy) dotyczących zarządzania gospodarczego w UE. Obowiązuje od 13 grudnia 2011 r. Wzmocnił unijny Pakt stabilności i wzrostu, European Parliament, Deeper and fairer economic and monetary union, Legislative Train 04/2019, http://www.europarl.europa.eu/legislative-train/api/stages/report/current/theme/deeper-and-fairer-economic-and-monetary-union/file/first-targeted-and-stability-oriented-revision-of-the-six-and-two-pack [dostęp: 21 maja 2019 r.].

${ }^{18}$ Nazwą „dwupak” określa się dwa rozporządzenia, które weszły w życie 30 maja 2013 r. we wszystkich krajach UGW. Ich celem jest wzmocnienie nadzoru budżetowego w strefie euro. Jest on uzupełnieniem unijnych przepisów w sferze finansowej, po przyjętym wcześniej tzw. sześciopaku. 
(czego wyrazem jest powołanie unii bankowej oraz prowadzenie prac w celu budowy unii rynków kapitałowych). Po trzecie, integrację polityki ekonomicznej, której celem jest zrównoważenie całej gospodarki strefy euro (poczynione kroki w tym kierunku to wzmocniony nadzór makroostrożnościowy czy też pakt Euro Plus $\left.{ }^{19}\right)^{20}$. W przedstawionym w 2015 r. tzw. raporcie pięciu prezydentów (podpisanym przez: szefa Komisji Europejskiej - Jean-Claude Junckera, przewodniczącego Rady Europejskiej - Donalda Tuska, kierującego Eurogrupą - Jeroena Dijsselbloema, przewodniczącego Parlamentu Europejskiego - Martina Schulza i prezesa Europejskiego Banku Centralnego - Mario Draghiego) pojawia się rok 2025, jako graniczna data dokończenia budowy UGW w jej nowym wymiarze, czyli unii opartej na czterech filarach: unii gospodarczej, finansowej, fiskalnej i politycznej ${ }^{21}$.

\section{Rynek finansowy strefy euro}

Rynek finansowy strefy euro to rynek obejmujący rynki finansowe 19 krajów należących do UGW. Integracja walutowa w istotny sposób wpłynęła na ich rynki finansowe. Chociaż nie można mówić o w pełni zintegrowanym rynku finansowym strefy euro, to niewątpliwie można mówić o widocznej integracji rynków finansowych tych krajów. Integracja widoczna jest zarówno, jeśli chodzi o standaryzację przepisów prawnych obowiązujących na rynkach finansowych w poszczególnych krajach członkowskich UGW, jak też jeśli chodzi o powiązania między rynkami.

Dynamika procesu integracji finansowej przebiegała w różnym tempie w różnych okresach. Szczególnie intensywny proces obserwowano przed wybuchem globalnego kryzysu finansowego ( $\mathrm{tj}$. przed rokiem 2007), kiedy to wdrażano dokument o nazwie „Plan działania w zakresie usług finansowych” (Financial

19 Pakt Euro Plus to plan zbliżenia gospodarek europejskich przez reformy strukturalne. Jego celem jest poprawa konkurencyjności strefy euro oraz wzmocnienie zaufania międzynarodowego rynku finansowego do wspólnej waluty euro. W Pakcie przewiduje się koordynację polityk w następujących dziedzinach: konkurencyjność, zatrudnienie, innowacje, koordynacja podatkowa czy stabilność finansów publicznych. Rząd polski wyraził zgodę (w 2011 r.) na przystąpienie Polski do Paktu Euro Plus. Zob. Komisja Europejska, The Euro Plus Pact, May 2015, https://ec.europa.eu/epsc/sites/epsc/files/strategic_note_issue_3.pdf [dostęp: 18 czerwca 2019 r.].

${ }^{20}$ M. Gotz, B.E. Nowak, A. Nowak-Far, W.M. Orłowski, Co dalej z euro? Trzy scenariusze dla Polski, Polska Fundacja im. Roberta Schumana, Warszawa 2017, s. 45, http://www.euroreg.uw.edu.pl/dane/web_euroreg_publications_files/6627/co-dalej-z-euro-raport-fundacji-schumana.pdf [dostęp: 17 maja 2019 r.].

${ }^{21}$ Komisja Europejska, The Five President's Report: Completing Europe's Economic and Monetary Union, 22 June 2015, https://ec.europa.eu/commission/publications/five-presidents-report-completing-europes-economic-and-monetary-union_en [dostęp: 21 kwietnia 2019 r.]. 
Services Action Plan, FSAP) ${ }^{22}$. W dokumencie tym nakreślono kierunek integracji rynku finansowego UE, podkreślając konieczność zbudowania jednolitego hurtowego rynku usług finansowych, budowę otwartego i bezpiecznego rynku detalicznego usług finansowych oraz przygotowanie odpowiednich regulacji w zakresie nadzoru nad rynkiem finansowym. Realizacja wytycznych zawartych w FSAP przebiegała w latach 1999-2005. W tym okresie Komisja Europejska wydała kilka dyrektyw, rozporządzeń, decyzji, rekomendacji i komunikatów, które stworzyły podwaliny prawne jednolitego rynku finansowego $\mathrm{UE}^{23}$. Realizacja FSAP rozpoczęła się przed utworzeniem strefy euro, tj. przed $2002 \mathrm{r}^{24}$, z myślą o wszystkich krajach UE. Po utworzeniu strefy euro była kontynuowana. Przyczyniła się do skokowej integracji rynków finansowych. Niemal pełna integracja została osiągnięta na hurtowym rynku międzybankowym oraz rynku obligacji rządowych, mniejsza na rynku obligacji korporacyjnych i w ramach bankowości inwestycyjnej, najniższy stopień integracji obserwowano na rynku akcji oraz w bankowości detalicznej ${ }^{25}$.

Proces integracji został przerwany wraz z początkiem w roku 2007 globalnego kryzysu finansowego, który doprowadził do zachwiania stabilności rynku finansowego strefy euro. Kolejne lata to próby radzenia sobie z negatywnymi skutkami kryzysu. Działania podejmowane w tym okresie polegały przede wszystkim na szukaniu rozwiązań, które wzmocniłyby rynek finansowy strefy euro, czyniąc go bardziej odpornym na kryzysy. Wśród istotnych zmian, które wprowadzono, było utworzenie unii bankowej.

Unia bankowa precyzuje wspólne zasady w zakresie nadzoru nad bankami działającymi w strefie euro (Single Supervisory Mechanizm, SSM), ich restrukturyzacji oraz uporządkowanej likwidacji (Single Resolution Mechanism, SRM), jak też gwarancji depozytów (Single Deposit Guarantee Scheme, SDGS) ${ }^{26}$.

Nadzór nad rynkiem finansowym UGW sprawowany jest przez Europejski System Nadzoru Finansowego, w skład którego wchodzą Europejska Rada ds. Ryzyka Systemowego (European Systemic Risk Board, ESRB) ${ }^{27}$ oraz cztery europejskie urzędy nadzoru (European Supervisory Authorities, ESA), tj.:

${ }^{22}$ Komisja Europejska, Financial Services Action Plan, Brussels 1999.

${ }_{23}$ T. Kowalak, Znaczenie Financial Services Action Plan dla budowy wspólnego rynku finansowego w Unii Europejskiej, „Ruch Prawniczy, Ekonomiczny i Socjologiczny” 2003, nr 3.

${ }^{24}$ Strefa euro powstała 1 stycznia 2002 r., kiedy waluta euro została wprowadzona w formie gotówkowej do obiegu w krajach członkowskich UGW (wcześniej, tj. od roku 1999 waluta euro była wykorzystywana $\mathrm{w}$ transakcjach bezgotówkowych).

${ }_{25}$ G. Tchorek, J. Czaja, Doświadczenia integracji rynków finansowych w strefie euro. Implikacje dla Polski [w:] Wprowadzenie euro w Polsce - za i przeciw, Wydawnictwo Sejmowe, Warszawa 2013, s. 83.

${ }^{26}$ European Banking Federation, Banking Union, https://www.ebf.eu/priorities/banking-supervision/banking-union, 26 August 2019 [dostęp: 2 września 2019 r.].

${ }_{27}$ Http://www.esrb.europa.eu/home/html/index.en.html [dostęp: 12 lipca 2019 r.]. 
Europejski Urząd Nadzoru Bankowego (European Banking Authority, EBA) ${ }^{28}$, Europejski Urząd Nadzoru Giełd i Papierów Wartościowych (European Securities and Markets Authority, ESMA) ${ }^{29}$, Europejski Urząd Nadzoru Ubezpieczeń i Pracowniczych Programów Emerytalnych (European Insurance and Occupational Pensions Authority, EIOPA) ${ }^{30}$ oraz Wspólny Komitet Europejskich Urzędów Nadzoru (Joint Committee). Ważną rolę w ramach jednolitego mechanizmu nadzorczego odgrywa Europejski Bank Centralny, który sprawuje nadzór nad największymi bankami krajów strefy euro (tj. bankami o aktywach przekraczających 30 mld euro) ${ }^{31}$. Obecnie w strefie euro działa 120 banków takiej wielkości ${ }^{32}$.

Odpowiedzialność za restrukturyzację i uporządkowaną likwidację została powierzona Jednolitej Radzie ds. Restrukturyzacji i Uporządkowanej Likwidacji (Single Resolution Board, SRD). Celem jej działania jest zapewnienie skutecznej restrukturyzacji oraz likwidacji tych instytucji finansowych, które są niewypłacalne ${ }^{33}$. Wsparciem finansowym dla działań podejmowanych przez Radę jest Jednolity Fundusz Restrukturyzacji i Uporządkowanej Likwidacji (Single Resolution Fund, SRF) ${ }^{34}$. SRD kontroluje wykonanie programu restrukturyzacji i uporządkowanej likwidacji, wspierając się krajowymi organami ds. restrukturyzacji i uporządkowanej likwidacji.

W ramach jednolitego systemu gwarantowania depozytów kraje UGW planują ujednolicenie reguł prawnych ochrony depozytów do wysokości 100 tys. euro $^{35}$. Działania w tym zakresie nie zostały jeszcze zrealizowane. Systemy gwarancyjne mają charakter systemów lokalnych, co oznacza, że są ustalane i monitorowane przez poszczególne kraje.

${ }^{28} \mathrm{Http} / /$ www.eba.europa.eu/languages/home_pl [dostęp: 17 sierpnia 2019 r.].

${ }^{29}$ Https://www.esma.europa.eu/ [dostęp: 28 maja 2019 r.].

${ }^{30} \mathrm{Https}$ ://eiopa.europa.eu/ [dostęp: 23 maja 2019 r.].

31 Rozporządzenie Rady (UE) nr 1024/2013 z 15 października 2013 r. powierzające Europejskiemu Bankowi Centralnemu szczególne zadania w odniesieniu do polityki związanej z nadzorem ostrożnościowym nad instytucjami kredytowymi, 13 września 2017 r., Dz.Urz. UE L 287/63 z 29 października 2013 r.

32 Lista banków nadzorowanych przez EBC, http://www.ecb.europa.eu/pub/pdf/other/ ssm-listofsupervisedentities1409en.pdf?7f491a3d1ffd265b97f0ed2d9a7d939e [dostęp: 18 maja 2019 r.].

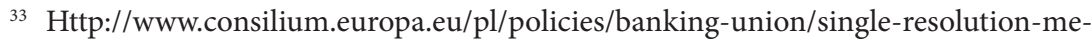
chanism/ [dostęp: 25 maja 2019 r.].

${ }^{34}$ PWC, EU Bank Recovery and Resolution Directive "Triumph or tragedy"?, https:// www.pwc.com/im/en/publications/assets/pwc_eu_bank_recovery_and_resolution_directive_triumph_or_tragedy.pdf [dostęp: 13 czerwca 2019 r.].

35 Dyrektywa Parlamentu Europejskiego i Rady 2009/14/WE z 11 marca 2009 r. zmieniająca dyrektywę 94/19/WE w sprawie systemów gwarancji depozytów w odniesieniu do poziomu gwarancji oraz terminu wypłaty, Dz.Urz. UE L 68/3 z 13 marca 2009 r. 
Unia bankowa obejmuje swym zasięgiem tylko kraje, które należą do UGW, natomiast inne kraje mają możliwość dobrowolnego przyłączenia się do niej. Obecnie przystąpienie do unii bankowej rozważa Szwecja i Dania.

Unia Europejska widzi potrzebę poszerzenia zakresu działania unii bankowej o kwestie dotyczące nowej roli EBC, tj. przypisanie mu roli pożyczkodawcy ostatniej instancji (the lender of last resort, LOLR) dla krajów strefy euro oraz dodatkowej roli w zakresie awaryjnej pomocy płynnościowej (emergency liquidity assistance, ELA) ${ }^{36}$. Obecne rozwiązania $\mathrm{w}$ tym zakresie w UE są mało przejrzyste $^{37}$, co wynika m.in. z braku precyzyjnego odniesienia się do tych kwestii podczas precyzowania celu działania eurosystemu (który obejmuje EBC oraz krajowe banki centralne państw członkowskich strefy euro (zgodnie z artykułem 127.1 TFUE nadrzędnym celem eurosystemu jest utrzymanie stabilności cen).

The lender of last resor to rola, którą krajowe banki centralne pełnią od wielu lat (koncepcja LOLR pojawiła się już w pracach dziewiętnastowiecznego ekonomisty brytyjskiego $\mathrm{H}$. Thortona ${ }^{38}$ ). Wypełniając tę funkcję, banki centralne wspomagają banki komercyjne w sytuacjach kryzysowych przez udzielanie im pożyczek (najczęściej pod zastaw bezpiecznych papierów dłużnych). Celem LOLR jest niedopuszczenie do rozprzestrzeniania się paniki na rynku bankowym. O ile można mówić o istnieniu ogólnoświatowego konsensusu w zakresie istotności tej funkcji, to jednak sposób jej realizacji jak też określenie potencjalnych beneficjentów są zróżnicowane ${ }^{39}$. Funkcja LOLR jest realizowana przez krajowe banki centralne wobec krajowych instytucji bankowych. Nie ma przykładów realizacji tej funkcji w skali międzynarodowej. UE chce podjąć próbę realizacji LOLR przez EBC w skali międzynarodowej, zwracając uwagę, że pojawiające się kryzysy finansowe (czego przykładem jest globalny kryzys finansowy zapoczątkowany w 2008 r. na rynku kredytów hipotecznych w Stanach Zjednoczonych) mają charakter międzynarodowy. Analiza aktów prawnych regulujących działanie banków centralnych w strefie euro (Traktatu o funkcjonowaniu Unii Europejskiej i statutu Europejskiego Systemu Banków Centralnych) pozwala stwierdzić, że nie ma tam bezpośredniego odniesienia do roli LOLR, co stworzyło przestrzeń do różnych interpretacji tej roli i jednocześnie zróżnicowania poglądów, co do działań, jakie może podejmować EBC w celu jej realizacji. Działania UE zmierzają do zmiany tej sytuacji.

${ }^{36}$ European Parliament, Happy birthday? The euro at 20. Monetary Dialogue, January 2019, s. 24, http://www.europarl.europa.eu/cmsdata/159709/DIW_final\%20publication.pdf [dostęp: 20 czerwca 2019 r.].

37 W. Stawasz-Grabowska, Pożyczkodawca ostatniej instancji w strefie euro. Nowa rola Europejskiego Banku Centralnego, Wydawnictwo Uniwersytetu Łódzkiego, Łódź 2018, s. 10.

${ }^{38} \mathrm{H}$. Thorton, An enquiry into the nature and effects of the paper credit of Great Britain, J. Hatchard, London 1802.

39 W. Stawasz-Grabowska, Pożyczkodawca, op. cit., s. 177-178. 
Emergency liquidity assistance obejmuje wsparcie krajowych banków centralnych dla pojedynczych instytucji kredytowych mających przejściowe problemy z płynnością. Wsparcie to jest udzielane w wyjątkowych sytuacjach (ELA wymaga przeprowadzenia szczegółowej analizy konkretnego przypadku). Decyzję o wsparciu finansowym podejmuje właściwy krajowy bank centralny, który działa w tym samym kraju, co bank dotknięty problemami z płynnością. Jednocześnie krajowy bank centralny ponosi koszty związane $\mathrm{z}$ tą operacją ${ }^{40}$. Jeżeli wielkość wsparcia dla pojedynczej instytucji kredytowej przekracza kwotę 500 mln euro, wówczas krajowy bank centralny jest zobowiązany jak najszybciej poinformować o tym $\mathrm{EBC}^{41}$. Rada Prezesów EBC może ograniczyć operacje typu ELA, jeśli kolidują one z celami eurosystemu ${ }^{42}$.

Operacje typu ELA realizowane są obecnie na szczeblu krajowym. UE planuje rozszerzyć je także na szczebel międzynarodowy, powierzając tę rolę EBC. Dotychczas EBC miał możliwość udzielania wsparcia płynnościowego bankom w dobrej kondycji finansowej, natomiast banki, które borykają się z problemami (ale nadal są wypłacalne) mogą liczyć jedynie na pomoc krajowych banków centralnych w ramach ELA ${ }^{43}$.

Istotną zmianę dla funkcjonowania rynku finansowego strefy euro przyniesie planowana unia kapitałowa. Pomysł jej utworzenia został przedstawiony w 2015 r. w dokumencie Komisji Europejskiej zatytułowanym Building a Capital Markets Union ${ }^{44}$. We wstępnym zarysie unia kapitałowa została zaprojektowana z myślą o wszystkich państwach Unii Europejskiej. Celem utworzenia unii kapitałowej jest przeniesienie ciężaru finansowania gospodarki z sektora bankowego na instytucje szeroko rozumianego rynku kapitałowego (czyli zwiększenie zasilania gospodarki przez kapitał pozabankowy). UE podkreśla, że kredyty bankowe odgrywają obecnie bardzo dużą rolę $\mathrm{w}$ finansowaniu sektora przedsiębiorstw w krajach europejskich (znacznie większą niż pozyskiwanie kapitału przez emisję dłużnych papierów wartościowych). Duża zależność gospodarki, a szczególnie małych i średnich przedsiębiorstw (MŚP) od kredytów bankowych sprawia, że przedsiębiorstwa są bardzo wrażliwe na zaostrzenie warunków udzielania kredytów przez banki (co można było obserwować podczas

40 Ibidem, s. 72-73.

41 EBC, Procedury dotyczace awaryjnego wsparcia płynnościowego, https://www.ecb.europa.eu/pub/pdf/other/201402_elaprocedures.pl.pdf?964ebea530dfa47828f5173d5d355113 [dostęp: 9 maja 2019 r.].

42 Art. 14 ust. 4 statutu Europejskiego Systemu Banków Centralnych i Europejskiego Banku Centralnego (dalej: statut ESBC)

43 European Parliament, Happy birthday?, op. cit., s. 24-25.

44 Komisja Europejska, Green Paper. Building a Capital Markets Union, 18 February 2015, http://ec.europa.eu/finance/consultations/2015/capital-markets-union/docs/green-paper_en.pdf [dostęp: 5 czerwca 2019 r.]. 
ostatniego globalnego kryzysu finansowego). Celem UE jest zmiana tej sytuacji. Realizacja unii kapitałowej potrwa jeszcze kilka lat ${ }^{45}$.

Oceniając reformy strefy euro z perspektywy ostatnich 20 lat, możemy mówić o źle zaprojektowanej architekturze finansowej strefy ${ }^{46}$, co niewątpliwie przyczyniło się do nadmiernego obciążenia Europejskiego Banku Centralnego, jak też do powstawania napięć politycznych ${ }^{47}$. Istotną wadą stosowanych rozwiązań było dopuszczenie do istnienia zależności finansowej między bankami i rządami państw. Wśród propozycji zmian tej sytuacji pojawiają się pomysły wprowadzenia dodatkowych obciążeń dla banków za nadmierne zaangażowanie w obligacje skarbowe, wzmocnienie mechanizmu bail-in, czyli zwiększenie udziału wierzycieli w pokrywaniu strat upadających banków, zwiększenie nadzoru nad bankami, jak też zaostrzenie i zharmonizowanie standardów regulacyjnych obowiązujących banki.

Przed wybuchem globalnego kryzysu finansowego w 2008 r. integracja rynku finansowego UE postrzegana była jako istotny czynnik wzrostu gospodarczego. Podkreślano, że rynki zintegrowane sprzyjają lepszej dywersyfikacji ryzyka oraz przyczyniają się do lepszej alokacji zasobów. Po wybuchu kryzysu zaczęto postrzegać integrację rynku finansowego jako niezbędny warunek zapewnienia stabilności działania rynku finansowego w ramach strefy euro. Dlatego też podkreśla się potrzebę przyspieszenia prac w celu zwiększenia stopnia integracji tego rynku. Kierunek ten został wyraźnie nakreślony w przywołanym wcześniej tzw. raporcie pięciu prezydentó ${ }^{48}$. Wskazano tam, że UGW powinna dążyć do stworzenia unii finansowej, która opierać się będzie na dwóch podstawowych filarach, tj. unii bankowej i unii rynków kapitałowych ${ }^{49}$. Również Europejski Urząd Nadzoru Bankowego w strategii na lata $2017-2020^{50}$ podkreślił, że dąży do zbudowania jednolitych zasad regulacyjnych i nadzorczych dla całego sektora bankowego UE (Single Rulebook). Dodatkowo w pakiecie reform przyjętych

${ }^{45}$ Komisja Europejska, Capital Markets Union: progress on building a Single Market for capital for a strong Economic and Monetary Union, March 2019, http://ec.europa.eu/finance/ docs/policy/190315-cmu-communication_en.pdf [dostęp: 4 czerwca 2019 r.].

${ }^{46}$ Reconciling risk sharing with market discipline: A constructive approach to euro area reform, Centre for Economic Policy Research, Policy Insight No. 91, January 2018, https:// cepr.org/sites/default/files/policy_insights/PolicyInsight91.pdf [dostęp: 17 maja 2019 r.].

${ }^{47}$ Napięcia polityczne wyraźnie widać na linii państw-dłużników i państw-wierzycieli. Ich źródłem są m.in. rozwiązania, jakie proponowała UGW krajom niewypłacalnym - proponowano pożyczki pod warunkiem wdrożenia surowych reform fiskalnych. Efektem podjętych działań był wzrost nastrojów nacjonalistycznych i populistycznych w strefie euro.

${ }^{48}$ Komisja Europejska, The Five President's Report, op. cit.

49 Ibidem, s. 10-11.

50 The EBA 2017 Work Programme, 30 September 2016, https://www.eba.europa.eu/do cuments/10180/1617016/2017+EBA+Work+Programme.pdf/34686907-c4db-4786-92c008940288b102, 6 December 2017 [dostęp: 19 maja 2019 r.]. 
podczas szczytu strefy euro w grudniu $2018 \mathrm{r}$. wezwano do przyspieszenia prac w zakresie budowy unii bankowej i unii kapitałowe ${ }^{51}$.

Rynek finansowy krajów strefy euro nie jest obecnie w pełni zintegrowany, można raczej mówić o pewnych wspólnych regulacjach obowiązujących w państwach członkowskich. Również stopień rozwoju rynków finansowych w poszczególnych krajach członkowskich UGW jest niejednolity. Rozpatrując wielkość rynku finansowego w krajach strefy euro do PKB poszczególnych krajów, widać ich spore zróżnicowanie. Przykładem dużych rozbieżności jest rynek grecki i irlandzki. W Grecji kapitalizacja rynku finansowego (obejmującego rynek akcji i obligacji) nie przekracza 50\% PKB, podczas gdy w Irlandii wskaźnik ten wynosi ponad $200 \%{ }^{52}$. Duże zróżnicowanie widać także, analizując efektywność działania rynków finansowych (financial market efficiency) oraz stopień dostępności rynków finansowych dla każdego uczestnika rynku finansowego (financial market access) $)^{53}$.

\section{Polska w strefie euro - konsekwencje dla polskiego rynku finansowego}

Rynek finansowy w Polsce od 2004 r. jest częścią rynku finansowego UE. Z uwagi na fakt, że Polska nie jest członkiem UGW, polski rynek finansowy nie jest częścią rynku finansowego strefy euro. Regulacje rynku finansowego w strefie euro nie odbiegają jednak w istotny sposób od tych obowiązujących w ramach UE. Większość z nich opracowywana jest bowiem z myślą o całym rynku finansowym UE. Dlatego też wejście Polski do strefy euro nie będzie wiązać się z potrzebą dokonywania radykalnych zmian.

Niemniej można wskazać przykłady nowych inicjatyw unijnych skierowanych przede wszystkim do krajów strefy euro. Taką inicjatywą jest unia bankowa. Kraje będące członkami strefy euro są członkami tej unii, podczas gdy kraje spoza strefy euro mogą przyłączyć się do niej na zasadzie bliskiej współpracy. Obecnie Polska nie jest członkiem unii bankowej i nie planuje przyłączenia się do tej inicjatywy. W momencie wejścia do UGW stanie się automatycznie jej członkiem, co pociągnie za sobą pewne konsekwencje - odpowiedzialność za stabilność sektora bankowego w Polsce zostanie przeniesiona na szczebel wspólnotowy, Polska przyłączy się do wspólnego mechanizmu zarządzania kryzysami. Członkostwo w unii bankowej będzie wiązać się z ponoszeniem dodatkowych kosztów przez banki w Polsce. Koszty te to składki na fundusz upadłości banków i składki na wspólny system gwarantowania depozytów.

${ }^{51}$ Euro Summit, Brussels, 14 December 2018, https://www.consilium.europa.eu/ media/37563/20181214-euro-summit-statement.pdf [dostęp: 12 maja 2019 r.].

${ }_{52}$ European Parliament, Happy birthday, op. cit., s. 17.

${ }^{53}$ Ibidem, s. 18-19. 
Wejście Polski do strefy euro wywrze zatem pewne skutki dla polskiego sektora bankowego. Oprócz skutków bezpośrednio związanych z przyłączenia się do unii bankowej można wskazać też inne, np. zmianę roli Narodowego Banku Polskiego, zmniejszenie dochodów osiąganych przez banki z tytułu prowizji, marż bankowych oraz wszelkiego typu opłat administracyjnych związanych z wymianą walut, podniesienie przez banki marż kredytowych, pojawienie się dodatkowych kosztów związanych z wymianą bankomatów, sorterów i innych maszyn wykorzystywanych w bankach, jak też kosztów związanych z wprowadzeniem nowych systemów informatycznych.

Przykładem kolejnego sektora rynku finansowego, gdzie będzie można obserwować skutki przystąpienia do strefy euro, jest rynek kapitałowy. Z jednej strony przyłączenie się do strefy euro stanie się dodatkowym impulsem do rozwoju rynku kapitałowego w Polsce z uwagi na zwiększenie konkurencji na tym rynku (zwiększy się również dostęp do kapitału), z drugiej jednak strony można przewidywać zmniejszenie obrotów na rynku instrumentów pochodnych. Bez wątpienia, po przystąpieniu do strefy euro rynek kapitałowy w Polsce w większym stopniu będzie chroniony przed atakami spekulacyjnymi.

\section{Skutki przystąpienia do strefy euro dla polskiego sektora bankowego}

Bardzo istotną konsekwencją wejścia Polski do strefy euro będzie zmiana roli Narodowego Banku Polskiego. Obecnie NBP jest odpowiedzialny za prowadzenie polityki pieniężnej w Polsce. Po wejściu do strefy euro zadanie prowadzenia polityki pieniężnej zostanie automatycznie scedowane na Europejski Bank Centralny. Będzie miało to istotne konsekwencje dla gospodarki Polski i możliwości amortyzowania szoków makroekonomicznych (polityka pieniężna przestanie być narzędziem umożliwiającym szybką reakcję na osłabienie koniunktury gospodarczej w naszym kraju). Utrata prawa do prowadzenia polityki pieniężnej oznacza także utratę możliwości ustalania referencyjnej stopy procentowej. Ponadto NBP utraci prawo do emisji pieniądza, jak też prawo do zarządzania rezerwami. Dodatkowo będzie się to wiązać z utratą zysków z tego tytułu (zwanych senioratem lub rentą menniczą) $)^{54}$.

Wejście Polski do strefy euro będzie skutkować eliminacją kosztów transakcyjnych związanych z wymianą walut. Chodzi tu zarówno o koszty wymiany złotego na euro, jak też koszty przelewów pieniędzy między różnymi krajami oraz koszty wynikające z zabezpieczania się przed ryzykiem kursowym. Z punktu widzenia wpływu wejścia do strefy euro na rynek bankowy w Polsce szczególnie istotna jest eliminacja kosztów wymiany walut realizowanej przez banki, jak też kosztów związanych z przelewami pieniędzy za granicę (chodzi tu o koszty prowizji, marż bankowych oraz wszelkiego typu opłat administracyjnych).

${ }^{54}$ Polska będzie jednak uprawniona do udziału w zysku EBC (proporcjonalnie do swojego udziału w kapitale banku), który będzie przekazywany do budżetu państwa. 
Zaowocuje ona zapewne zmniejszeniem dochodów osiąganych przez banki (obecnie koszt transferu pieniędzy z Polski do strefy euro wynosi 1,19 euro za 10 euro i 50 euro przy transakcji 10 tys. euro ${ }^{55}$ ). Dodatkowo banki utracą dochody związane z wypłatą pieniędzy z polskiego rachunku w bankomacie w strefie euro (średnie marże, jakie pobierały banki przy wymianie złotego na euro, wynosiły w 2018 r. od 0,30 do 2,37 euro za 10 euro) $)^{56}$.

Spadek dochodów banków z tytułu wymiany walut może zostać w pewnym stopniu zrekompensowany przez podniesienie przez banki marż kredytowych. Działanie takie może wynikać z obniżenia oprocentowania kredytów bankowych w Polsce i próby wykorzystania tego faktu przez banki poprzez podniesienie marż w celu zwiększenia swoich dochodów. Obecnie oprocentowanie kredytów bankowych w Polsce jest wyższe niż w krajach strefy euro (średnie oprocentowanie kredytów hipotecznych w Polsce w 2018 r. wynosiło 4,4\%, podczas gdy np. w Belgii to 1,95\%, w Finlandii 0,86\%, a we Włoszech 1,89\%) $)^{57}$. Różnice w oprocentowaniu wynikają z dwóch czynników. Po pierwsze, jest to efekt utrzymywania przez NBP wyższych stóp referencyjnych niż te określane przez EBC ( $z$ uwagi na fakt, że banki ustalają oprocentowanie kredytów na podstawie stóp referencyjnych banku centralnego, ich wysokość bezpośrednio przekłada się na wysokość oprocentowania kredytów - im wyższe, tym oprocentowanie kredytów jest też wyższe). Po drugie, na wysokość stóp procentowych w Polsce wpływa tzw. premia za ryzyko, która zależy m.in. od stabilności polskiego systemu finansowego oraz płynności rynku kapitałowego, jak też przewidywań dotyczących inflacji czy zmienności kursu złotego. Po wstąpieniu Polski do strefy euro premia za ryzyko zostałaby zredukowana, co automatycznie zaowocowałoby obniżeniem oprocentowania kredytów bankowych. Niższe koszty kredytu to szansa na zwiększenie akcji kredytowej przez banki (z uwagi na większe zainteresowanie przedsiębiorstw i banków kredytowaniem), co niewątpliwie będzie kolejnym źródłem dochodów bankowych.

Należy też zauważyć, o czym już była mowa wcześniej, że banki w Polsce w momencie przystąpienia do strefy euro poniosą koszty wymiany bankomatów, sorterów i innych maszyn, jak też koszty wprowadzenia nowych systemów informatycznych.

Wejście do strefy euro oznacza automatyczne przeniesienie na szczebel wspólnotowy odpowiedzialności za stabilność sektora bankowego w Polsce oraz

${ }_{55}$ Komisja Europejska, Study on the extension of Regulation 924/2009 to currencies of Member States outside the euro area Final Report, 2018, s. 33, https://ec.europa.eu/info/sites/ info/files/180328-study-cross-border-transaction-fees-extension_en.pdf [dostęp: 14 czerwca 2019 r.]

56 Ibidem, s. 45.

57 Quarterly Review of European Mortgage Markets, European Mortgage Federation (4/2018), s. 13, https://hypo.org/app/uploads/sites/3/2019/04/EMF-Q4-2018-FINAL.pdf [dostęp: 4 maja 2019 r.]. 
przyłączenie się do wspólnego mechanizmu zarządzania kryzysowego. Nadzór nad największymi bankami w Polsce, tj. bankami, których aktywa przekraczają 30 mld euro, przejmie Europejski Bank Centralny (w Polsce działają trzy banki o takiej wielkości: PKO Bank Polski, Pekao SA oraz Santander Bank).

Obecna sytuacja w sektorze bankowym w Polsce jest stabilna, banki osiągają dobre wyniki finansowe, dlatego też nie można powiedzieć, że wstąpienie do unii bankowej przyniesie wymierne korzyści w tym zakresie.

Stabilność działania sektora bankowego w Polsce z jednej strony jest wynikiem dobrego zarządzania bankami, z drugiej strony konieczności przestrzegania przez banki licznych regulacji wynikających z prawa bankowego, jak też regulacji unijnych, które obowiązują banki w Polsce. Wśród takich regulacji jest m.in. dyrektywa CRD IV (Capital Requirements Package IV Directive) (58 $^{58}$ oraz rozporządzenie CRR (Capital Requirements Regulation) $)^{59}$, tj. dwa akty, które określają podstawowe ramy prawne dotyczące działania banków na rynku unijnym. W dokumentach tych wskazano wymagania odnośnie do wysokości funduszy własnych banków działających w UE, norm płynności, które muszą przestrzegać, oraz wysokości dźwigni finansowej. Ponadto uregulowano kwestie dotyczące buforów kapitałowych, oceny ryzyka kredytowego, ładu korporacyjnego oraz wynagrodzenia kadry kierowniczej.

Stabilność działania sektora bankowego w Polsce dodatkowo zwiększa powołany w sierpniu 2015 r. Komitet Stabilności Finansowej (KSF), którego celem jest sprawowanie nadzoru makroostrożnościowego, czyli monitorowanie ryzyka systemowego $^{60}$.

Stabilność banków potwierdzają stress testy przeprowadzone w $2018 \mathrm{r}$. przez Europejski Urząd Nadzoru Bankowego ${ }^{61}$. Stress testom były poddane dwa największe banki polskie, tj. PKO BP i Pekao SA, które osiągnęły bardzo dobre wyniki, świadczące o dużej stabilności ich działania. Podobne wnioski płyną ze stress testów przeprowadzonych przez NBP także w roku 2018. Badano wpływ hipotetycznych szoków na banki w Polsce w okresie od III kwartału 2018 r. do

${ }^{58}$ Dyrektywa Parlamentu Europejskiego i Rady 2013/36/UE z 26 czerwca 2013 r. w sprawie warunków dopuszczenia instytucji kredytowych do działalności oraz nadzoru ostrożnościowego nad instytucjami kredytowymi i firmami inwestycyjnymi, zmieniająca dyrektywę 2002/87/WE i uchylająca dyrektywy 2006/48/WE oraz 2006/49/WE, Dz.Urz. UE L 176, t. 56, 27 czerwca $2013 \mathrm{r}$.

59 Rozporządzenie Parlamentu Europejskiego i Rady (UE) nr 575/2013 z 26 czerwca 2013 r. w sprawie wymogów ostrożnościowych dla instytucji kredytowych i firm inwestycyjnych, zmieniające rozporządzenie (UE) nr 648/2012, Dz.Urz. UE L 176, t. 56, 27 czerwca $2013 \mathrm{r}$.

${ }^{60}$ Ustawa z 5 sierpnia 2015 r. o nadzorze makroostrożnościowym nad systemem finansowym i zarządzaniu kryzysowym w systemie finansowym, Dz.U. poz. 1513.

${ }^{61}$ EBA, 2018 EU-wide stress test results, 2 November 2018, https://eba.europa.eu/ documents/10180/2419200/2018-EU-wide-stress-test-Results.pdf [dostęp: 3 czerwca 2019 r.]. 
końca 2020 r. Wyniki stress testów wskazały, że prawdopodobieństwo materializacji ryzyka systemowego (którego efektem byłoby zakłócenie świadczenia usług pośrednictwa finansowego przez banki) jest niskie ${ }^{62}$.

Banki w Polsce osiągają dobre wyniki finansowe. Wynik netto dla całego sektora bankowego w Polsce na koniec 2018 r. wyniósł ponad 14,7 mld zł ${ }^{63}$ (w 2017 r. - 13,6 mld zł ${ }^{64}$ ). Spełniają też wymogi dotyczące funduszy własnych przewidziane w pakiecie CRD/CRR. Dodatkowo można powiedzieć, że nie mają problemów z płynnością finansową. Wszystkie banki komercyjne spełniają standard unijny w zakresie płynności krótkoterminowej (tzw. LCR, Liquidity Coverage Ratio $)^{65}$ na wymaganym poziomie $100 \%{ }^{66}$. Wyzwaniem dla banków pozostaje jednak spełnienie standardów unijnych w zakresie płynności długoterminowej (która określana jest wskaźnikiem NSFR, Net Stable Funding Ratio ${ }^{67}$ ). Obecnie polskie banki są finansowane głównie depozytami krajowymi (ich udział w finansowaniu aktywów stanowi 61\%), natomiast kapitały rynkowe stanowią niewielki udział w ich finansowaniu (zaledwie 19\% aktywów bankowych finansowanych jest w ten sposób) ${ }^{68}$. Aby sprostać wymaganiom w zakresie NSFR, banki powinny emitować więcej papierów wartościowych (w tym m.in. listów zastawnych). Docelowo wielkość wskaźnika NSFR powinna wynosić minimum $100 \%$ i powinna być osiągnięta przez polskie banki do roku $2023^{69}$.

Niewątpliwie utrzymywaniu się dobrej sytuacji banków w Polsce sprzyja otoczenie makroekonomiczne, np. trwające ożywienie gospodarcze, stabilna sytuacja finansowa przedsiębiorstw czy też poprawa sytuacji na rynku pracy ${ }^{70}$.

${ }^{62}$ Narodowy Bank Polski, Raport o stabilności systemu finansowego, grudzień 2018 r., s. 118, https://www.nbp.pl/systemfinansowy/rsf122018.pdf [dostęp: 22 maja 2019 r.].

${ }^{63} \mathrm{KNF}$, Information on the situation of banks in the period I-IX 2018, Warsaw 2018, s. 11.

${ }^{64}$ KNF, Raport o sytuacji banków w 2017, Warszawa 2018, https://www.knf.gov.pl/knf/ pl/komponenty/img/RAPORT_O_SYTUACJI_BANKOW_2017_12_61471.pdf [dostęp: 30 kwietnia 2019 r.].

${ }^{65}$ Płynność krótkoterminowa jest mierzona za pomocą wskaźnika pokrycia płynności krótkoterminowej (LCR). Wyraża on proporcję między wysokiej jakości płynnymi aktywami a wypływami pieniężnymi netto w ciągu 30-dniowego okresu.

${ }^{66} \mathrm{KNF}$, Information on the situation, op. cit., s. 11.

${ }^{67}$ NSFR jest wyliczany przez odniesienie dostępnej kwoty stabilnych źródeł finansowania (available amount of stable funding, AASF) do sumy pozycji wymagających pokrycia stabilnymi źródłami finansowania (required amount of stable funding, RASH). Celem wprowadzenia NSFR jest mobilizacja banków do przejścia z finansowania krótkoterminowego na finansowanie średnio- i długoterminowe.

${ }_{68}$ Komisja Europejska, Country Report Poland 2019, 2019, s. 24-25, https://ec.europa. eu/info/sites/info/files/file_import/2019-european-semester-country-report-poland_en.pdf [dostęp: 2 czerwca 2019 r.].

${ }^{69}$ Basel III: The Net Stable Funding Ratio, Basel Committee on Banking Supervision, Consultative Document, January 2014, s. 3, http://www.bis.org/publ/bcbs271.pdf [dostęp: 24 maja 2019 r.].

70 Komisja Europejska, Country Report, op. cit., s. 3. 
Członkostwo Polski w unii bankowej wiązać się będzie z dodatkowymi kosztami ponoszonymi przez banki związanymi z ratowaniem podmiotów sektora bankowego. Koszty te to: składki na fundusz upadłości banków czy też składki na system gwarantowania depozytów (system przewidziany dla unii bankowej).

Bilans korzyści i strat związanych z wejściem Polski do unii bankowej trudno precyzyjnie określić z uwagi na niepewność co do wystąpienia kryzysów bankowych w przyszłości. Niewątpliwie można powiedzieć, że koszty wynikające z członkostwa w unii bankowej pojawią się od razu po włączeniu do niej Polski, natomiast korzyści mogą pojawić się w przyszłości, przede wszystkim w czasie kryzysów bankowych.

\section{Skutki przystąpienia do strefy euro dla rynku kapitałowego w Polsce}

Przyłączenie się do strefy euro stanie się dodatkowym impulsem do rozwoju rynku kapitałowego w Polsce z uwagi na zwiększenie konkurencji na tym rynku. Inwestorzy będą mieli większy dostęp do instrumentów notowanych na innych rynkach. Zwiększy się również dostęp inwestorów do kapitału. Z punktu widzenia Polski szczególnie korzystny byłby dostęp do nowych obligacji, tzw. obligacji stabilnościowych (stability bonds) ${ }^{71}$. Gwarantem takich obligacji byłyby wszystkie kraje strefy euro. Chociaż obligacje tego typu nie zostały jeszcze wprowadzone, to jednak ekonomiści (m.in. noblista J.E. Stiglitz ${ }^{72}$ ) podkreślają potrzebę ich emisji. Obecnie każdy kraj emituje obligacje we własnym imieniu (ich rentowność jest różna, co odzwierciedla ich ryzyko). Emisją takich obligacji zainteresowane są w szczególności kraje zadłużone, z uwagi na to, że ich emisja zwiększałaby wiarygodność mocno zadłużonych krajów w oczach kredytobiorców i tym samym zyskałyby one dostęp do tańszego kapitału. Z punktu widzenia rozwoju rynku finansowego UE wprowadzenie nowych papierów wartościowych, jakimi są obligacje stabilnościowe, pozwoliłoby na budowę w UE rynku obligacji, który swoim rozmiarem oraz stopniem płynności odpowiadałby rynkowi amerykańskiemu.

Wejście Polski do strefy euro będzie zapewne skutkować zmniejszeniem obrotów na rynku instrumentów pochodnych w Polsce. Obecnie wielu eksporterów zabezpiecza się przed ryzykiem kursowym przez zakup instrumentów finansowych, takich jak np. kontrakty terminowe, swapy czy też opcje walutowe, co poważnie wpływa na obroty notowane na tym rynku (według danych za 2018 r. tego typu rozwiązania stosowało 44\% przedsiębiorstw rozliczających sprzedaż zagraniczną w euro ${ }^{73}$ ). Eliminacja ryzyka kursowego, z uwagi na zastąpienie złotego walutą euro, sprawi, że tego typu transakcje staną się bezzasadne. Oczywiście, nie można przewidywać załamania tego rynku, tak z uwagi na wy-

${ }^{71}$ Europe's Political Spring, Fixing the Eurozone and Beyond, eds. A. Bénassy-Quéré, F. Giavazzi, CEPR, 2017, s. 3.

72 J.E. Stiglitz, Euro. W jaki sposób wspólna waluta zagraża przyszłości Europy, Wydawnictwo Krytyki Politycznej, Warszawa 2017, s. 321.

73 A. Czerniak, A. Smoleńska, Polska bez euro. Bilans kosztów i korzyści, op. cit., s. 18. 
korzystywanie instrumentów pochodnych jako zabezpieczenie przed ryzykiem kursowym w transakcjach z krajami spoza strefy euro, jak też z uwagi na fakt, że instrumenty pochodne wykorzystywane są przez inwestorów nie tylko w celach zabezpieczania się, ale także w celach spekulacyjnych.

Wejście Polski do strefy euro jest równoważne z przeniesieniem odpowiedzialności za prowadzenie polityki pieniężnej z Narodowego Banku Polskiego na Europejski Bank Centralny. Oznacza to jednocześnie, że podmiotem odpowiedzialnym za określanie wysokości stóp procentowych obowiązujących w Polsce będzie $\mathrm{EBC}^{74}$. Stopy EBC są niższe niż stopy $\mathrm{NBP}^{75}$, co pozwala założyć, że stopy procentowe w Polsce po wejściu do strefy euro ulegną obniżeniu ${ }^{76}$. Będzie to miało istotne konsekwencje dla rynku kapitałowego w Polsce. Wysokość stóp procentowych wpływa z jednej strony na skłonność podmiotów gospodarczych do oszczędzania, z drugiej natomiast na skłonność do zaciągania kredytów bankowych. Efektem obniżki stóp procentowych jest zazwyczaj obniżenie skłonności podmiotów gospodarczych do oszczędzania w bankach (z uwagi na spadek oprocentowania depozytów) oraz wzrost zainteresowania kredytami (z uwagi na obniżenie ich kosztów) ${ }^{77}$. Podmioty gospodarcze (z uwagi na zwiększoną dostępność środków finansowych) zwiększają wydatki na inwestycje, m.in. inwestycje w papiery wartościowe. Wzrost zainteresowania podmiotów gospodarczych inwestycjami giełdowymi (w akcje czy obligacje) zwiększy napływ pieniądza na rynek kapitałowy, co może być dodatkowym impulsem do jego rozwoju. Należy też zauważyć, że wzrost popytu na rynku kapitałowym może skutkować wzrostem cen instrumentów finansowych notowanych na tym rynku.

Bez wątpienia, po przystąpieniu do strefy euro rynek kapitałowy w Polsce $\mathrm{w}$ większym stopniu będzie chroniony przed atakami spekulacyjnymi. W ramach drugiego filaru unii bankowej, czyli jednolitego mechanizmu restruk-

${ }^{74} \mathrm{EBC}$ określa trzy podstawowe stopy procentowe, tj.

- krańcową stopę procentową (marginal lending facility rate), czyli stopę, po jakiej banki centralne krajów należących do strefy euro oferują pożyczki bankom komercyjnym,

- stopę depozytową (deposit facility rate), czyli stopę oprocentowania jednodniowych depozytów składanych przez banki komercyjne w narodowych bankach centralnych,

- stopę repo podstawowych operacji finansowych (main ferinancing operations rate), czyli oprocentowanie siedmiodniowych papierów wartościowych operacji refinansowych, które przeprowadza EBC.

${ }^{75}$ Różnice między stopami EBC a stopami procentowymi NBP wynikają m.in. z rozbieżności strukturalnych między gospodarką Polski i strefą euro. Polska znajduje się wciąż w fazie „doganiania” gospodarek wysoko rozwiniętych.

${ }^{76}$ Narodowy Bank Polski, Raport na temat pełnego uczestnictwa Rzeczpospolitej Polskiej w trzecim etapie Unii Gospodarczej i Walutowej, Warszawa 2009, s. 104, https://www.nbp.pl/ publikacje/o_euro/re.pdf [dostęp: 12 czerwca 2019 r.].

77 J. Stawska, Stopy procentowe a inwestycje w Polsce i strefie euro, Wydział Ekonomiczno-Socjologiczny Uniwersytetu Łódzkiego, Łódź 2014, s. 52. 
turyzacji i uporządkowanej likwidacji (SRM) utworzono Jednolity Fundusz Restrukturyzacji i Uporządkowanej Likwidacji, który dysponuje kapitałem w wysokości 50 mld euro, gwarantowanym linią kredytową z Europejskiego Mechanizmu Stabilności ${ }^{78}$. Fundusz ten jest dostępny tylko dla krajów strefy euro, co oznacza, że Polska będzie mogła z niego korzystać dopiero po wejściu do tej strefy. Podstawowa korzyść, jaka płynie z tego faktu, to ograniczenie ryzyka powstania baniek spekulacyjnych w Polsce. W przypadku bowiem zagrożenia atakiem spekulacyjnym Polska będzie miała dostęp do dużego kapitału, co umożliwi podjęcie bardziej efektywnych działań zapobiegających sytuacji kryzysowej. Zgodnie z szacunkami A. Czerniaka członkostwo w strefie euro w bardzo istotny sposób ogranicza ryzyko powstania baniek spekulacyjnych na giełdach krajów, które posługują się wspólną walutą ${ }^{79}$.

Rynek kapitałowy w Polsce od wielu lat dynamicznie się rozwija. Dużą dynamikę zmian obserwuje się zarówno na rynku regulowanym dla akcji i instrumentów pochodnych, jak też alternatywnym rynku NewConnect dla spółek wzrostowych czy rynku obligacji korporacyjnych i komunalnych Catalyst. Wśród zalet polskiego rynku kapitałowego niewątpliwie można wskazać bezpieczeństwo obrotu i usług posttransakcyjnych, jak też rozwiniętą infrastrukturę. System transakcyjny Giełdy Papierów Wartościowych (GPW) należy do najnowocześniejszych na świecie, a spółki notowane na giełdzie odznaczają się wysokimi standardami w zakresie ładu korporacyjnego i komunikacyjnego.

Wejście Polski do strefy euro można zatem postrzegać jako dodatkowy impuls do rozwoju rynku kapitałowego, niemniej nie jest to warunek dalszego rozwoju.

O dobrej kondycji polskiego rynku kapitałowego świadczą m.in. decyzje podjęte w 2018 r. przez agencję indeksową FTSE Russell oraz firmę Stoxx, operatora indeksów Deutsche Boerse Group. W 2018 r. obie te agencje zakwalifikowały Polskę do grupy krajów rozwiniętych (developed markets) ${ }^{80}$. Polska jako jedyny kraj z Europy Środkowo-Wschodniej znalazła się w grupie 25 najbardziej rozwiniętych światowych gospodarek, takich jak Stany Zjednoczone, Wielka Brytania, Niemcy, Francja, Japonia czy Australia. Pozostałe kraje Europy Środkowo-Wschodniej klasyfikowane są w grupie krajów rozwijających się (emerging markets). Zakwalifikowanie Polski do grupy krajów rozwiniętych stwarza szansę na zwiększenie zainteresowania zagranicznych inwestorów (szczególnie funduszy inwestycyjnych) akcjami polskich spółek ${ }^{81}$. Niewątpliwie wpłynie to na

78 Ibidem, s. 28.

79 A. Czerniak, Asset Price Bubbles in Monetary Union: Mind the Convergence Gap, 2019.

80 Dokonując klasyfikacji, FTSE Russell wzięła pod uwagę m.in.: jakość rynku kapitałowego, otoczenie regulacyjne, infrastrukturę, kształt systemu depozytowo-rozliczeniowego, jak też stopień rozwoju rynku instrumentów pochodnych.

81 Z danych statystycznych wynika, że ok. 87\% funduszy inwestuje na rynkach kapitałowych najbardziej rozwiniętych państw. Kraje rozwijające się mogą liczyć zaledwie na 
dodatkowy rozwój rynku kapitałowego w Polsce, chociaż należy mieć na uwadze fakt, że przebudowa portfeli funduszy inwestycyjnych potrwa zapewne kilka lat.

W lutym 2019 r. Ministerstwo Finansów przedstawiło projekt strategii rozwoju rynku kapitałowego w Polsce ${ }^{82}$. W projekcie określono kluczowe wyzwania, przed jakimi stoi polski rynek kapitałowy, jak też bariery dalszego rozwoju. Głównym celem rozwoju rynku przedstawionym w projekcie jest poprawa dostępu polskich przedsiębiorstw do finansowania. Aby to osiągnąć, niezbędne jest obniżenie kosztów pozyskiwania kapitału przez przedsiębiorstwa, zwiększenie płynności rynku kapitałowego, jak też zwiększenie efektywności działania instytucji pośredniczących oraz efektywności procedur administracyjnych.

\section{Podsumowanie}

Wejście Polski do strefy euro wywrze pewien wpływ na rynek finansowy w Polsce, niemniej nie można mówić o radykalnych zmianach na tym rynku. Zarówno rynek bankowy, jak też rynek kapitałowy w Polsce odznaczają się obecnie wysokim stopniem rozwoju i dużą dynamiką zmian w zakresie postępu technologicznego, co pozwala mówić o bardzo dobrej kondycji obu sektorów.

Dla sektora bankowego w Polsce wejście do strefy euro będzie się wiązało $\mathrm{z}$ jednej strony $\mathrm{z}$ koniecznością ponoszenia dodatkowych opłat (związanych m.in. z wymianą bankomatów, sorterów czy wprowadzaniem nowych systemów informatycznych, jak też wpłat na fundusz upadłości banków, system gwarantowania depozytów czy też uczestnictwo w programach pomocowych ${ }^{83}$ ) i utratą pewnych dochodów (bezpośrednio związanych $\mathrm{z}$ wymianą walut), z drugiej natomiast szansą na pozyskanie dodatkowych dochodów (wynikających np. z wyższych marż kredytowych).

Dla rynku kapitałowego jest to z jednej strony szansa na dalszy, dynamiczny i stabilny rozwój, z drugiej jednak - można przewidywać zmniejszenie obrotów w niektórych segmentach, np. na rynku instrumentów pochodnych.

Niewątpliwie istotną korzyścią wynikającą ze wstąpienia do strefy euro dla polskiego rynku finansowego jest lepsze zabezpieczenie Polski przed skutkami kryzysów. Nowym mechanizmem wsparcia, z którego mogą korzystać kraje strefy euro w sytuacjach kryzysowych, jest Europejski Mechanizm Stabilizacji Finansowej (European Financial Stabilisation Mechanism, EFSM), który dysponuje kapitałem w wysokości 500 mld euro. Obecnie Polska ma dostęp do znacznie

zainteresowanie 13\% funduszy, https://www.money.pl/gielda/wiadomosci/artykul/gpw-ftse-russell-przekwalifikowal-polske-do,111,0,2416751.html [dostęp: 30 maja 2019 r.].

${ }_{82}$ Ministerstwo Finansów, Strategia rozwoju rynku kapitałowego - projekt, Warszawa 2018.

${ }^{83}$ N. Stoupos, A. Kiohos, Post-Communist countries of the EU and the euro: dynamic linkages between exchange rates, „Acta Oeconomica” 2017, Vol. 67(4), s. 527, https://akademiai. com/doi/pdf/10.1556/032.2017.67.4.2. [dostęp: 26 kwietnia 2019 r.]. 
niższych funduszy [w ramach programu BoP - Balance-of-payments assistance programme, Europejskiego Instrumentu Stabilności Finansowej (European Financial Stability Facility, EFSF) oraz Europejskiego Mechanizmu Stabilizacji ${ }^{84}$. $Z$ drugiej jednak strony można mówić o zwiększeniu podatności Polski na wystąpienie tzw. efektu zarażania, co oznacza, że kryzys w którymkolwiek kraju UGW wywrze istotny wpływ na sytuację na rynku finansowym w Polsce.

Wskazanie wszystkich konsekwencji przystąpienia Polski do strefy euro dla polskiego rynku finansowego jest trudne $\mathrm{z}$ uwagi na brak jednolitej koncepcji rynku finansowego strefy euro. Wśród krajów członkowskich UGW występują bardzo istotne różnice w postrzeganiu docelowego jego kształtu. Część krajów opowiada się za wprowadzaniem dodatkowych mechanizmów stabilizacyjnych i instrumentów zarządzania ryzykiem na poziomie całej strefy euro ${ }^{85}$, część natomiast jest zdania, że dodatkowe instrumenty stabilizacji i podziału ryzyka w strefie euro nie przyniosą oczekiwanych rezultatów, wręcz mogą wywołać skutki negatywne. Zdaniem tych krajów główny nacisk należy położyć na ściślejsze egzekwowanie reguł fiskalnych i większą dyscyplinę rynkową, co, ich zdaniem, jest niezbędne, aby kraje strefy euro prowadziły odpowiedzialną politykę budżetową (co przełoży się bezpośrednio na zwiększenie stabilności finansowej poszczególnych krajów, a tym samym całej strefy euro) ${ }^{86}$. Przekonanie o niemożności pogodzenia tych stanowisk doprowadziło do impasu w zakresie reformowana strefy euro. Jak podkreślają jednak ekonomiści wiodących uczelni francuskich i niemieckich w opracowaniu Reconciling risk sharing with market discipline: A constructive approach to euro area reform ${ }^{87}$, przekonanie takie jest fałszywe. W ich opinii przyszła architektura finansowa strefy euro powinna obejmować zarówno mechanizmy stabilizacyjne i instrumenty zarządzania ryzykiem działające na szczeblu całej strefy euro, jak też tworzenie zachęt do prowadzenia przez kraje członkowskie strefy euro odpowiedzialnej polityki budżetowej i egzekwowanie jej ${ }^{88}$.

Określenie jasnej i jednolitej koncepcji rozwoju rynku finansowego strefy euro jest warunkiem niezbędnym dla prowadzenia dalszych rozważań na temat wpływu przystąpienia Polski do strefy euro na polski rynek finansowy.

${ }^{84}$ C. Alcidi, D. Gros, J. Núñez, F.D. Rinaldi, The Instruments Providing Macro-Financial Support to EU Member States, CEPS Research Report No 2017/06, March 2017, s. 1, https:// www.ceps.eu/wp-content/uploads/2017/03/RRpt\%20No\%202017-06\%20MacroFinSupport\%20to\%20MSs_0.pdf [dostęp: 12 maja 2019 r.].

${ }^{85}$ Stanowisko takie przyjmują m.in. Francja i Włochy.

${ }^{86}$ Stanowisko takie przyjmują m.in. Niemcy i Holandia.

${ }^{87}$ Reconciling risk sharing with market discipline: A constructive approach to euro area reform, Centre for Economic Policy Research, POLICY INSIGHT No. 91, January 2018, s. 1, https://cepr.org/sites/default/files/policy_insights/PolicyInsight91.pdf [dostęp: 28 kwietnia 2019 r.].

${ }^{88}$ Ibidem. 


\section{Bibliografia}

Alcidi C., Gros D., Núñez J., Rinaldi F.D., The Instruments Providing Macro-Financial Support to EU Member States, CEPS Research Report No 2017/06, March 2017, https://www.ceps.eu/wp-content/uploads/2017/03/RRpt\%20No\%202017-06\%20 MacroFinSupport\%20to\%20MSs_0.pdf.

Basel III: The Net Stable Funding Ratio, Basel Committee on Banking Supervision, Consultative Document, January 2014, http://www.bis.org/publ/bcbs271.pdf.

Europe's Political Spring, Fixing the Eurozone and Beyond, eds. A. Bénassy-Quéré, F. Giavazzi, CEPR, 2017.

Biała Księga w sprawie przyszłości Europy. Refleksje i scenariusze dotyczace przyszłości UE-27 do 2025 r., Komisja Europejska, Bruksela 2017, https://ec.europa.eu/commission/sites/beta-political/files/biala_ksiega_w_sprawie_przyszlosci_europy_pl.pdf.

Czerniak A., Asset Price Bubbles in Monetary Union: Mind the Convergence Gap, 2019.

Czerniak A., Smoleńska A., Polska bez euro. Bilans kosztów i korzyści, Polityka Insight, 2019, https://www.politykainsight.pl/en/_resource/multimedium/20164985.

EBA, 2018 EU-wide stress test results, 2 November 2018, https://eba.europa.eu/ documents/10180/2419200/2018-EU-wide-stress-test-Results.pdf.

European Banking Federation, Banking Union, https://www.ebf.eu/priorities/banking-supervision/banking-union.

ECB, A Fiscal Compact for a Stronger economic and Monetary Union, Monthly Bulletin, May 2012, https://www.ecb.europa.eu/pub/pdf/other/art1_mb201205en_pp79-94en.pdf? ea087c02b73d02418533c67ea0d36c1c.

ECB, Procedury dotyczące awaryjnego wsparcia płynnościowego, https://www.ecb.europa. eu/pub/pdf/other/201402_elaprocedures.pl.pdf?964ebea530dfa47828f5173d5d355113

Euro Summit, Brussels, 14 December 2018, https://www.consilium.europa.eu/media/ 37563/20181214-euro-summit-statement.pdf.

European Commission, Vade Mecum on the Stability \& Growth Pact, 2019, https:// ec.europa.eu/info/sites/info/files/economy-finance/ip101_en.pdf.

European Parliament, Deeper and Fairer Economic and Monetary Union, Legislative Train 04/2019, http://www.europarl.europa.eu/legislative-train/api/stages/report/ current/theme/deeper-and-fairer-economic-and-monetary-union/file/first-targeted-and-stability-oriented-revision-of-the-six-and-two-pack.

European Parliament, Happy birthday? The euro at 20. Monetary Dialogue, January 2019, http://www.europarl.europa.eu/cmsdata/159709/DIW_final\%20publication.pdf.

European Parliament, The European Stability Mechanism: Main Features, Instruments and Accountability, 2019, http://www.europarl.europa.eu/RegData/etudes/ BRIE/2014/497755/IPOL-ECON_NT(2014)497755_EN.pdf

Gotz M., Nowak B.E., Nowak-Far A., Orłowski W.M., Co dalej z euro? Trzy scenariusze dla Polski, Polska Fundacja im. Roberta Schumana, Warszawa 2017, http://www.euroreg.uw.edu.pl/dane/web_euroreg_publications_files/6627/co-dalej-z-euro-raport-fundacji-schumana.pdf. 
KNF, Information on the situation of banks in the period I-IX 2018, Warsaw 2018.

KNF, Raport o sytuacji banków w 2017, Warszawa 2018, https://www.knf.gov.pl/knf/pl/ komponenty/img/RAPORT_O_SYTUACJI_BANKOW_2017_12_61471.pdf.

Komisja Europejska, The Five President's Report: Completing Europe's Economic and Monetary Union, 22 June 2015, https://ec.europa.eu/commission/publications/five-presidents-report-completing-europes-economic-and-monetary-union_en.

Komisja Europejska, Green Paper. Building a Capital Markets Union Brussels, 18 February 2015, http://ec.europa.eu/finance/consultations/2015/capital-markets-union/docs/ green-paper_en.pdf.

Kowalak T., Znaczenie Financial Services Action Plan dla budowy wspólnego rynku finansowego w Unii Europejskiej, „Ruch Prawniczy, Ekonomiczny i Socjologiczny” 2003, nr 3. Ministerstwo Finansów, Strategia rozwoju rynku kapitałowego - projekt, Warszawa 2018. Narodowy Bank Polski, Raport na temat pelnego uczestnictwa Rzeczpospolitej Polskiej w trzecim etapie Unii Gospodarczej $i$ Walutowej, 2009, https://www.nbp.pl/ publikacje/o_euro/re.pdf.

Narodowy Bank Polski, Raport o stabilności systemu finansowego, grudzień 2018 r., https://www.nbp.pl/systemfinansowy/rsf122018.pdf.

PWC, EU Bank Recovery and Resolution Directive „Triumph or tragedy”?, https://www. pwc.com/im/en/publications/assets/pwc_eu_bank_recovery_and_resolution_directive_triumph_or_tragedy.pdf, 13 September 2017.

Quarterly Review of European Mortgage Markets, European Mortgage Federation (4/2018), https://hypo.org/app/uploads/sites/3/2019/04/EMF-Q4-2018-FINAL.pdf.

Reconciling risk sharing with market discipline: A constructive approach to euro area reform, Centre for Economic Policy Research, POLICY INSIGHT No. 91, January 2018, https://cepr.org/sites/default/files/policy_insights/PolicyInsight91.pdf.

Stawasz-Grabowska W., Pożyczkodawca ostatniej instancji w strefie euro. Nowa rola Europejskiego Banku Centralnego, Wydawnictwo Uniwersytetu Łódzkiego, Łódź 2018.

Stawska J., Stopy procentowe a inwestycje w Polsce i strefie euro, Wydział Ekonomiczno-Socjologiczny Uniwersytetu Łódzkiego, Łódź 2014.

Stiglitz J.E., Euro. W jaki sposób wspólna waluta zagraża przyszłości Europy, Wydawnictwo Krytyki Politycznej, Warszawa 2017.

Stoupos N., Kiohos A., Post-Communist countries of the EU and the euro: dynamic linkages between exchange rates, „Acta Oeconomica” 2017, Vol. 67(4), https://akademiai. com/doi/pdf/10.1556/032.2017.67.4.2.

Tchorek G., Czaja J., Doświadczenia integracji rynków finansowych w strefie euro. Implikacje dla Polski [w:] Wprowadzenie euro w Polsce - za i przeciw, Wydawnictwo Sejmowe, Warszawa 2013.

The EBA 2017 Work Programme, 30 September 2016, https://www.eba.europa.eu/docu ments/10180/1617016/2017+EBA+Work+Programme.pdf/34686907-c4db-478692c0-08940288b102.

Thorton H., An enquiry into the nature and effects of the paper credit of Great Britain, J. Hatchard, London 1802. 


\section{Akty prawne}

Dyrektywa Parlamentu Europejskiego i Rady 2009/14/WE z 11 marca 2009 r. zmieniająca dyrektywę 94/19/WE w sprawie systemów gwarancji depozytów w odniesieniu do poziomu gwarancji oraz terminu wypłaty, Dz.Urz. UE L 68/3 z 13 marca 2009 r.

Dyrektywa Parlamentu Europejskiego i Rady 2013/36/UE z 26 czerwca 2013 r. w sprawie warunków dopuszczenia instytucji kredytowych do działalności oraz nadzoru ostrożnościowego nad instytucjami kredytowymi i firmami inwestycyjnymi, zmieniająca dyrektywę 2002/87/WE i uchylająca dyrektywy 2006/48/WE oraz 2006/49/ WE, Dz.Urz. UE L 176, t. 56, 27 czerwca 2013 r.

Rozporządzenie Parlamentu Europejskiego i Rady (UE) nr 575/2013 z 26 czerwca 2013 r. w sprawie wymogów ostrożnościowych dla instytucji kredytowych i firm inwestycyjnych, zmieniające rozporządzenie (UE) nr 648/2012, Dz.Urz. UE L 176, t. 56, 27 czerwca $2013 \mathrm{r}$.

Rozporządzenie Rady (UE) nr 1024/2013 z 15 października 2013 r. powierzające Europejskiemu Bankowi Centralnemu szczególne zadania w odniesieniu do polityki związanej z nadzorem ostrożnościowym nad instytucjami kredytowymi, Dz.Urz. UE L 287/63 z 29 października 2013 r.

Traktat o funkcjonowaniu Unii Europejskiej, Dz.Urz. UE C 326/47 z 26 października $2012 \mathrm{r}$.

Ustawa z 5 sierpnia 2015 r. o nadzorze makroostrożnościowym nad systemem finansowym i zarządzaniu kryzysowym w systemie finansowym, Dz.U. poz. 1513.

\section{Strony internetowe}

Http://www.esrb.europa.eu.

Http://www.eba.europa.eu.

Https://www.esma.europa.eu.

Https://eiopa.europa.eu.

Http://www.consilium.europa.eu/pl. 